\title{
TRAVEL AND TOURISM INDUSTRY DEVELOPMENT - THE CASE OF KOSOVO
}

\author{
Idriz KOVAÇI * \\ University of Applied Sciences in Ferizaj, Faculty of Tourism and Environment, Street "University”, 70000, Ferizaj, \\ Kosovo, e-mail: idriz.kovaci@ushaf.net
}

\begin{abstract}
Alberta TAHIRI
University of Applied Sciences in Ferizaj, Faculty of Tourism and Environment, Street "University”, 70000, Ferizaj, Kosovo, e-mail: alberta.tahiri@ushaf.net

\section{Fari BUSHI}

University of Applied Sciences in Ferizaj, Faculty of Tourism and Environment, Street "University", 70000, Ferizaj, Kosovo, e-mail: fari.bushi@ushaf.net
\end{abstract}

Citation: Kovaçi, I., Tahiri, A., \& Bushi, F. (2020). Travel and Tourism Industry Development-The Case of Kosovo. Analele Universităţii din Oradea, Seria Geografie, 30(2), 147-156. https://doi.org/10.30892/auog.302104-844

\begin{abstract}
This paper presents a brief theoretical summary related to the development of the travel and tourism industry. The purpose of this paper is to make clear the importance of the development of the travel and tourism industry nowadays, knowing that these industries are developing rapidly. What characterizes this paper is the presentation of the case of Kosovo, which is illustrated with some statistics of tourism development in this country.
\end{abstract}

Key words: travel, tourism, travel and tourism industry, development

$* \quad * \quad * \quad * \quad * \quad *$

\section{INTRODUCTION}

Our intention in this paper is to make clear the importance of the development of the travel and tourism industry, as part of the life of the population worldwide. Knowing that many people are tired of the daily routine of work, they take trips to get out of this routine and relax. Thus, we can say that travel and tourism are part of our lives.

The development of tourism affects the country's economy. This paper presents the case of tourism development in Kosovo where we will see in more detail that the current situation of the tourism sector in Kosovo in terms of cooperation and exchange of data with international tourism organizations is very unsatisfactory, as Kosovo is not marked nor included in various tourism statistical reports for comparison of countries and regions, tourism trends, etc. Also, statistics show that the number of foreign tourists to visit Kosovo mainly increases from one year to another. Kosovo is very rich in natural beauty and opportunities for the development of 
various types of tourism, but what needs to be done is to use these opportunities for development and the most positive effects.

Tourism is a growing industry all over the world in recent years. In many war affected countries it has been noted that national investors and international investors have engaged themselves in investing more on the tourism industry as well as they are more eagerly waiting to invest more in the near future (Sivesan, 2020).

As one of the main and most dynamic activities in the world economy and the effects it creates, tourism is considered as one of the global economic phenomena. Its role is widely accepted by all governments of countries in the world, as one of the main indicators of economic growth. At the same time, tourism is recognized for its social, political and cultural impacts and environmental impacts. The World Tourism and Travel Council's research clearly speaks to the potential that tourism has for strengthening the global economy and reducing unemployment. In addition to the economic factor that is encouraged by tourism, direct benefits are also realized in the main tourism sectors, such as: hotels, restaurants, transport and retail (Tahiri and Kovaçi, 2017).

Tourism is now recognized as being an economic activity of global significance. Importance of the activity has increased, so too has the attention given to it by governments, organizations in both the public and private sectors, and academics.

The new challenges facing the tourism industry, as well as its specific characteristics and structure, are creating a need for more in-depth knowledge about the factors that affect and shape this industry. The importance of the tourism industry to the economy has been extensively demonstrated (Herman et al., 2017, 2018; Segui-Amortegui et al., 2019).

Tourism is an activity which cuts across conventional sectors in the economy. It requires inputs of an economic, social, cultural and environmental nature. In this sense it is often described as being multi-faceted. The problem in describing tourism as an "industry" is that it does not have the usual formal production function, nor does it have an output which can physically be measured, unlike agriculture (tonnes of wheat) or beverages (litres of whisky). There is no common structure which is representative of the industry in every country. In France and Italy, for example, restaurants and shopping facilities are major attractions for tourists; in Russia they are not. Even the core components of the tourism industry, such as accommodation and transport, can vary between countries. In the UK many tourists use bed and breakfast accommodation in private houses; in Thailand such facilities are not available. In the transport sector, levels of car ownership and developed road networks cause many tourists to use their cars or buses in Western Europe and the USA. In India and Indonesia, most tourists travel by air. It is some of these problems of definition which have caused many writers to refer to the tourist sector rather than the tourist industry. Sometimes the terms are used interchangeably (Lickorish and Jenkins, 1997).

The tourism industry is often cited as an attractive agent of development or redevelopment, generating employment and foreign exchange in a destination (Pender and Sharpley, 2005). The tourism sector, even if it seeks to be socially inclusive and permit access to different resources, has to address an ongoing problem (Page, 2019).

The relationship between tourism and the natural environment is complex (Ilieș et al., 2017; Tătar et al., 2017; Wendt et al., 2019). On the one hand, tourism depends on the world's natural resources, its diverse ecosystems and its rich biodiversity. A quality environment is the natural capital of tourism destinations, with income from tourism providing financial returns from investment in that capital. On the other hand, tourism uses vast quantities of resources and is a generator of emissions and pollution, both of which drive climate change. It is estimated that tourism accounts for $5 \%$ of global carbon dioxide $\left(\mathrm{CO}_{2}\right)$ emissions - it may contribute even more to global warming if all greenhouse gas (GHG) emissions are counted (UNWTO, 2018).

\section{TRAVEL AND TOURISM INDUSTRY}

The simple word travel, defined as "the act of moving" by most dictionaries, has a different definition within the context of the tourism industry. Travel is defined as "the act of moving outside 
one's community for business or pleasure but not for commuting or traveling to or from work or school". With respect to travel as an industry, there must also be economic value creation resulting from travel activity. Understanding the fundamental definitions and concepts used within the travel and tourism industry provides an essential framework from which most industry discussions are based. Because of tourism's intangible nature, common definitions of terminology benefit the industry in a number of ways (Gee and Solá-Fayos, 1997).

The notion of tourism is related to travel, but not to all travel, only to those which are motivated by the desire for rest, recreation, with a trip for the purpose of rest, recreation and visits to natural beauty and cultural and historical heritage values (Reçica and Millaku, 2014).

In one definition tourism is described as: the totality of relationships and phenomena arising from the travel and the stay of non-residents, provided that this stay doesn't create a permanent stay and from this stay isn't derived any profitable activity (Koja and Gorica, 2010).

Tourism has grown significantly since the creation of the commercial airline industry and the advent of the jet airplane in the 1950's. By 1992, it had become the largest industry and largest employer in the world. Together with this growth there have emerged a number of extremely critical issues facing the industry in terms of the impacts it has already had on destination areas and its residents, and the future prospects for people and places into the coming decades (Theobald, 2005).

One of the major issues in gauging tourism's total economic impact is the diversity and fragmentation of the industry itself. Theobald suggests that this problem is compounded by the lack of comparable tourism data since there has been no valid or reliable means of gathering comparable statistics. He proposes that the varying definitions of tourism terms internationally, and the complex and amorphous nature of tourism itself have led to difficulty in developing a valid, reliable, and credible information system or database about tourism and its contribution to local, regional, national and global economies. Davidson links the question of whether tourism is really an industry to the misunderstanding, resistance and hostility that often plague proponents of travel and tourism as worthy economic forces in a modern economy. He questions the common practice, especially as suggested in the literature of referring to tourism as an industry. He contends that such a designation may not be correct, and that tourism is not an industry at all. He states that much of the current misunderstanding, resistance and even hostility plaguing proponents of tourism may be due to its mistakenly being called an industry. Three arguments for tourism's designation as an industry are: It needs to gain the respect it now lacks among other competing economic sectors; It needs sound, accurate and meaningful data in order to assess its economic contribution, and; It needs to provide a sense of self-identity to its practitioners (Theobald, 2005).

\section{FORMS AND CATEGORIES OF TRAVEL}

Just as there are different types of visitors, there are different forms and categories of travel which take place, varying by traveler, destination, and motive for travel, such as: International vs. domestic travel; Intraregional vs. interregional travel, as well as; Inbound vs. outbound travel.

\section{INTERNATIONAL AND DOMESTIC TOURISM}

According to the WTO, international tourism differs from domestic tourism and occurs when the traveler crosses a country's border. Not every international traveler is a visitor, however. The traveler is a visitor only if the trip takes him or her outside the usual environment, e.g., workers who cross borders for employment are not considered visitors. The interest in international tourism has always been strong, primarily for economic reasons, as this form of tourism plays an important role in trade and monetary flows among nations. Domestic tourism has been overshadowed by the interest in international tourism, for it was thought initially to have little or no international impact, and statistics on the subject were felt to be a country's own business. It has become clear, however, that international and domestic tourism do relate to each other. Travelers' choices change depending on circumstances, and domestic tourism can be substituted for international tourism and vice versa under the influence of external factors, such as relative growth in real incomes, price differences 
between countries, and international political conditions. Over the past few decades, in many Western countries domestic holidays were largely replaced by outbound holidays, influenced by the rise in living standards and discretionary incomes, while developing countries have seen sharp increases in domestic tourism (Gee and Solá-Fayos, 1997).

\section{REGIONAL TRAVEL}

Regions are geographically united subdivisions of a larger area characterized by definitive criteria or frames of reference. Three types of regions are used in tourism research. The first one refers to geographical location. Regions such as "the north" or "the west", are examples of this type. The second type refers to administrative areas, such as "Province X". The third combines criteria referring to location with criteria of a more physical nature. Examples of this type of region are "the lake district" or "the Pacific Basin." Regions of functional type can also be constructed, such as "urban areas" or "coastal areas". The term inter-regional travel refers to travel among various regions, whether in regions found within the same province or state, a country, or various regions throughout the world. Intra-regional, on the other hand, refers directly to travel contained within the same defined region, whether domestic or international such as travel between countries of East Asia (Gee and Solá-Fayos, 1997).

\section{INBOUND AND OUTBOUND TOURISM}

There are three forms of tourism at any level, in relation to a given area, e.g., domestic region, country, or group of countries: Domestic tourism, involving residents of the given area traveling (as visitors) only within that area; Inbound tourism, involving non-residents traveling as visitors in the given area; Outbound tourism, involving residents traveling as visitors in an area other than the given area.

If a country is the area of reference, the terms "domestic," "inbound" and "outbound" tourism can be combined in various ways to derive the following categories of tourism: Internal tourism, which comprises domestic and inbound tourism; National tourism, which comprises domestic tourism and outbound tourism; International tourism, which consists of inbound tourism and outbound tourism.

To avoid misunderstanding the terms "inbound", "outbound", "domestic", "internal", "national" and "international tourism" are generally used with a country as the unit of reference. However, it should be recognized that there are political subdivisions which are less than countries and differ from states such as the Commonwealth of Puerto Rico and the Commonwealth of the Northern Mariana Islands, both part of the United States (Gee and Solá-Fayos, 1997).

\section{THE NATURE AND CHARACTERISTICS OF THE TOURISM INDUSTRY}

The amorphous nature of the tourism industry has made it difficult to evaluate its impact on the economy relative to other sectors in the economy. Techniques have been developed to facilitate measurement of impact but there is no universally accepted definition of what constitutes the tourism industry. The World Tourism Organization (WTO) has attempted to address this problem in its publication A Standard Industrial Classification of Tourism Activities (SICTA). Most academic writers tend to craft their definitions to suit their specific purposes. The definition given by Burkart and Medlik (1981) is accepted: the phenomenon arising from temporary visits (or stays away from home) outside the normal place of residence for any reason other than furthering an occupation remunerated from within the place visited.

However, there are a number of features associated with tourism which are quite explicit. For example, tourism implies that a person undertakes a journey: the journey may be for less than a day (day tripper/visitor); or it may be a journey within a national boundary, therefore constituting a domestic tourist trip; or it might be a journey which crosses an international boundary, therefore being classified as an international tourism trip. However, it is not only the nature of the journey which constitutes tourism, but is also the purpose of the journey which very broadly should be for 
leisure or business. In looking at the development of tourism historically, most attention has been given to the concept of international tourism, i.e. journeys across international boundaries. Although the components of the tourism industry will differ between countries, there are certain subsectors which are clearly identified as being components of tourism activity, such as the accommodation sector which would include not only formal accommodation, hotels, guest houses, etc., but also camping sites, rooms in private houses and bed and breakfast type arrangements. Travel agents and tour operators are recognized as comprising another distinct subsector. Transport - airlines, shipping, rail and car hire, cars and coaches - will also be seen as being important inputs to the tourism sector. In some countries, shopping and production of handicrafts is another associated activity of tourism (Lickorish and Jenkins, 1997).

\section{THE DEVELOPMENT OF THE TOURISM INDUSTRY}

Development is an ambiguous term that, although widely applied in many and diverse contexts, defines precise definition. Broadly, however, it is considered to be both the process through which a nation or society moves from one condition towards another (presumably better) condition and also the goal of that process. On other words, it "refers both to the destination of a journey and to the journey itself". Despite this ambiguity, not only has "development" long been considered both a desirable outcome and specific objective of tourism development but also, for many destinations as well as organizations such as the UNWTO, it continues to be seen in this light (Sharpley, 2020).

Over the five decades, tourism has experienced continued growth and deepening diversification to become one of the fastest growing economic sectors in the world. Modern tourism is closely linked to development and encompasses a growing number of new destinations (Baker and Unni, 2018). It is evident that tourism is in a close relationship with many other sectors. This encounters many difficulties as well as some opportunities (Işik et al., 2019).

If we use 1945 as being the year when the development of the major growth in the tourism industry began, we can make some general observations relating to the changes which one can discern in the tourism industry.

Before the 1950s, tourism was very much an industry which was fragmented; hotels, transport operators, travel agents, tour operators all tended to work independently of each other. Hotels were largely in the business of selling bed nights. Airlines and railways were in the business of selling seats. Travel agents of course, were selling travel and holidays but in each case they tended to operate very much as individual businesses. From the mid-1950s onwards, particularly in the UK, the growth of tour operators began to change the nature of the industry from essentially individual business activities to more integrated activities. Hotels, for example, were beginning to see customers as wanting a range of services rather than simply buying accommodation. So hotels began to develop shopping arcades and later to offer secretarial centres to try to increase the spend of guests within the hotel complex. Transport operators, particularly in the airline business, saw the sale of transport services as being integral to a much wider need. Airlines offered insurance and accommodation booking for travellers. By the 1980s many airlines were offering complete travel services including holiday arrangements, medical services, car hire, etc.

What we have seen since the 1950s is the emergence of a holiday and travel industry which is offering more integrated services. This is particularly noticeable with the forward and backward integration of some of the very large tour operators. To some extent this was determined by the nature of demand. In other cases it was a business opportunity to integrate demand and provide a service at a much more competitive price and to maintain and increase market share. By 1990 the structure of the tourism industry, certainly in the UK and Europe, was influenced by the growth of some very large companies. In the USA, American anti-trust laws discouraged, if not prohibited, the development of large integrated companies. The American experience in tour operation has been very different from that within Europe, particularly compared with the UK (Lickorish and Jenkins, 1997). 


\section{TOURISM GLOBAL DEVELOPMENT}

That tourism is a global phenomenon is not debated. However, the definition and nature of the phenomena collectively known as global tourism are frequently debated and misunderstood. "Global", as a term, is not the major source of confusion. It refers to the fact that visitor flows, tourism advertising, flows of spending by visitors and tourism enterprises, the ownership of tourism enterprises, and the collection and reporting of tourism statistics reach around the world and form a complex web of interconnections and dependencies among tourism businesses and organizations. The confusion stems from the nature of "tourism" itself (Lew et al., 2004).

It is important to recognize that international tourism, although considered an industry, is more accurately a set of industries, including railroads, airlines, automobile rental companies, hotels, restaurants, food and beverage producers, travel agencies, communications firms, museums, souvenir makers and sellers, and various entertainments. Significantly, many of these industries compete internationally, need large capital investments, require development of local infrastructures, and increasingly rely on strategic alliances and centralized coordination (Belk and Costa, 1995).

Tourism, as a curious quest for something that is novel and different, involves spaces and people's social relations to spaces, simply because novelty and difference exist not at home but elsewhere (Wang, 2000).

Globalisation is a concept that is increasingly invoked in the analysis of tourism. With the seemingly limitless spread of tourism, the embracing of virtually any form of activity and the general ubiquity of tourists and tourism, the temptation to reference globalisation in discussions of tourism has been irresistible, often through casual and uncritical statements (Mowforth and Munt, 2016).

Tourism and its development prospects in the world matter too many countries, regions and continents of the globe. From the level and dynamics of international tourism development many countries and regions have changed the landscape physiognomy. From backward and underdeveloped areas have become functional tourist areas, in which there is a genuine tourist offer. International tourism in the world in the past century has reached an extremely high level. The development of international tourism and the progress of its development are related to the political and economic situation in the world and different areas and regions. Tourism as an important economic activity is related to the circumstances created in the world economy. In the fifty years the level of international tourism development has been harmonized with the development of the world economy and the movement of the standard of living (real increase in wages and leisure). However, tourism has grown faster than the world economy and living standards. There is no doubt that in this act and other factors, such as: the rapid development of urbanization and motorization in developing countries has created the need for foreign tourism demand and extensive state and large capital jobs in the developing famous tourist sites with fast developing tourism industry in all fields. The latter is related with the tendency to increase tourism through export opportunities to those countries with favorable natural and other conditions for tourism development (Reçica and Millaku, 2011).

\section{TOURISM INDUSTRY IN KOSOVO}

Tourism today is one of the most important and dynamic sectors of the world economy and is considered to be a complex and diverse phenomenon. It is complex as it involves the performance of a large number of activities (e.g. water, rail, road and air transport services to hotels, restaurants, souvenir shops, banks and retail) that are organized and coordinated with each other.

\section{KOSOVO AND INTERNATIONAL ORGANIZATIONS FOR TOURISM AND STATISTICS}

An important issue for tourism development in Kosovo is its membership in various international organizations that are directly involved in tourism, or indirectly contribute to the collection and comparison of tourism data. The current situation of the tourism sector in Kosovo in terms of cooperation and exchange of data with international tourism organizations is very unsatisfactory, as Kosovo is neither listed nor included in the various tourism statistical reports for comparison of countries and regions, tourism trends, etc. 
Memberships and collaborations with organizations of this nature are very useful and recommended when preparing national tourism strategies and are considered as an extremely important tool in measuring the level of progress in achieving country-specific tourism objectives. Furthermore, the lack of appropriate local, regional and national data on the tourism sector in Kosovo presents a major challenge and makes it difficult for policymakers to develop strategies and set objectives for the sector. When compared to Kosovo, regional countries such as Albania, Macedonia, Montenegro, etc., are already full members or candidates for membership in various international tourism organizations. As noted in various reports on tourism, these countries use and consult closely the reports and findings of international tourism organizations as valuable resources for the development of tourism strategies.

In the table below, there is a list of international organizations related to collecting and comparing tourism data.

Table 1. International organizations that contribute to the collection, analysis and measurement of tourism data Source: Analysis of the current situation in the tourism sector in Kosovo, 2018

\begin{tabular}{|c|c|}
\hline \multicolumn{2}{|r|}{ Main international organizations for tourism and statistics } \\
\hline 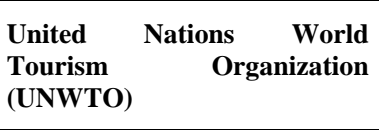 & $\begin{array}{l}\text { "A United Nations agency responsible for promoting responsible, sustainable and } \\
\text { inclusive tourism. It generates market knowledge, promotes competitive and } \\
\text { sustainable tourism policies and instruments, and promotes tourism education and } \\
\text { training". }\end{array}$ \\
\hline $\begin{array}{l}\text { World Council on Travel and } \\
\text { Tourism (WTTC) }\end{array}$ & $\begin{array}{l}\text { "The WTTC works to raise awareness of Travel \& Tourism as one of the largest } \\
\text { sectors in the world. The WTTC advocates for partnerships between the public and } \\
\text { private sectors, delivering results that match the needs of economies, local and } \\
\text { regional authorities, and local communities, with business ones". }\end{array}$ \\
\hline Eurostat & $\begin{array}{l}\text { "It provides the EU with statistics at European level that allow comparisons } \\
\text { between countries and regions". }\end{array}$ \\
\hline $\begin{array}{lr}\text { Travel and } & \text { Tourism } \\
\text { Competitiveness } & \text { Index } \\
\text { (World Economic } & \text { Forum) }\end{array}$ & $\begin{array}{l}\text { "This index is a measure of the factors that make business development in the travel } \\
\text { and tourism industry of individual countries attractive, rather than a measure of the } \\
\text { country's attractiveness as a tourist destination". }\end{array}$ \\
\hline $\begin{array}{l}\text { European Travel Commission } \\
\text { (ETC) }\end{array}$ & $\begin{array}{l}\text { "It's a non-profit organization responsible for promoting Europe as a tourist } \\
\text { destination in third markets". }\end{array}$ \\
\hline 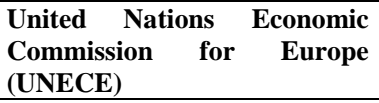 & $\begin{array}{l}\text { "It aims to promote pan-European economic integration and facilitate greater } \\
\text { economic integration and cooperation among member countries". }\end{array}$ \\
\hline $\begin{array}{l}\text { United Nations Educational, } \\
\text { Scientific and Cultural } \\
\text { Organization (UNESCO) }\end{array}$ & $\begin{array}{l}\text { "It is responsible for coordinating international cooperation in education, science, } \\
\text { culture and communication. It strengthens the links between nations and societies, } \\
\text { and mobilizes the general public". }\end{array}$ \\
\hline $\begin{array}{l}\text { United Nations Statistics } \\
\text { Division (UNSTATS) }\end{array}$ & $\begin{array}{l}\text { "It is committed to advancing the global statistical system. UNSTATS aims to } \\
\text { compile and disseminate global statistical information, develop standards and norms } \\
\text { for statistical activities, and support countries' efforts to strengthen their national } \\
\text { statistical systems". }\end{array}$ \\
\hline
\end{tabular}

\section{STATISTICS FOR TOURISM DEVELOPMENT IN KOSOVO}

Despite the lack of institutional support and investment in the tourism sector, the number of international travelers visiting Kosovo has progressively increased from 24,616 in 2008 to 79,234 in 2015. The regions most visited by international guests in Kosovo in 2015 are Pristina $(53,057)$, Peja $(12,694)$ and Prizren $(9,779)$. The data available for this sector is very limited. Tourism is assumed to directly contribute more than $1 \%$ to Kosovo's GDP and employs more than 9,000 people (3.5\% of total employment), while the world average tourism contribution to GDP is 3.3\%. Public investment (human and financial) in this sector is negligible. The ministry responsible for tourism development is the Ministry of Trade and Industry, with a Division of Tourism employing three full-time public officials. Kosovo Investment and Enterprise Support Agency (KIESA) is the public institution responsible for promoting tourism. Both organizations commit very small amounts of money to develop the sector (less than 100,000 euros a year). Unlike the central level, the commitment (product development, promotion and launch of public-private projects) of some municipalities such as Peja, Prizren and Gjakova for tourism development has been significantly higher. 
Table 2. Number of foreign visitors and their nights of stay by country of origin in the period 2016-2018 Source: Kosovo Agency of Statistics, Series 3: Economic Statistics, Hotel Statistics Q1 2019

\begin{tabular}{|c|c|c|c|c|c|c|c|}
\hline \multirow{2}{*}{$\begin{array}{l}\text { Order } \\
\text { No. }\end{array}$} & \multirow[b]{2}{*}{ Country } & \multicolumn{2}{|c|}{2016} & \multicolumn{2}{|c|}{2017} & \multicolumn{2}{|c|}{2018} \\
\hline & & Visitors & Nights & Visitors & Nights & Visitors & Nights \\
\hline 1 & Austria & 7,493 & 11,309 & 5,719 & 9.138 & 5,076 & 8,809 \\
\hline 2 & Belgium & 2,735 & 4,209 & 2,995 & 5,300 & 3,156 & 6,034 \\
\hline 3 & $\begin{array}{l}\text { Bosnia and } \\
\text { Herzegovina }\end{array}$ & 2,705 & 4,071 & 2,460 & 4,436 & 3,360 & 5,231 \\
\hline 4 & Great Britain & 5,514 & 9,698 & 5,034 & 8,400 & 6,482 & 10,113 \\
\hline 5 & France & 3,756 & 6,027 & 4,084 & 7,014 & 4,496 & 7,184 \\
\hline 6 & Germany & 14,225 & 24,425 & 16,579 & 28,283 & 17,178 & 28,668 \\
\hline 7 & Greece & 1,290 & 2,624 & 1,441 & 4,414 & 2,593 & 9,448 \\
\hline 8 & Netherlands & 2,480 & 4,748 & 2,666 & 5,321 & 3,107 & 5,564 \\
\hline 9 & Italy & 4,946 & 7,725 & 5,023 & 8,299 & 6,292 & 10,253 \\
\hline 10 & Croatia & 5,401 & 8,775 & 4,344 & 7,304 & 5,926 & 10,421 \\
\hline 11 & Montenegro & 3,098 & 4,799 & 2,889 & 5,082 & 3,901 & 6,843 \\
\hline 12 & Macedonia & 6,155 & 9,602 & 6,251 & 10,504 & 7,842 & 12,554 \\
\hline 13 & Poland & 661 & 1,157 & 671 & 1,059 & 503 & 891 \\
\hline 14 & Serbia & 6,089 & 9,173 & 6,108 & 9,461 & 7,475 & 12,222 \\
\hline 15 & US & 12,238 & 21,703 & 10,539 & 18,796 & 13,857 & 21,862 \\
\hline 16 & Albania & 29,509 & 41,293 & 28,158 & 40,263 & 37,141 & 53,669 \\
\hline 17 & Slovenia & 6,192 & 11,771 & 6,848 & 13,093 & 6,690 & 13,394 \\
\hline 18 & Spain & 325 & 532 & 375 & 636 & 650 & 2,059 \\
\hline 19 & Turkey & 12,667 & 20,928 & 13,463 & 21,880 & 14,848 & 23,938 \\
\hline 20 & Switzerland & 11,001 & 18,989 & 12,494 & 23,165 & 13,151 & 21,741 \\
\hline 21 & Other & 25,506 & 43,526 & 24,088 & 41,549 & 29,035 & 50,431 \\
\hline & Total & 163,986 & 267,084 & 162,229 & 264,268 & 192,759 & 321,329 \\
\hline
\end{tabular}

The table above shows statistics on the number of tourists and their night stays by country of origin in the period 2016-2018. We note that the largest number of tourists come from Albania (37,141 tourists in 2018), Germany (17, 178 tourists in 2018) and Turkey (14,848 tourists in 2018). Mostly the number of tourists has increased from one year to another.

Also the Kosovo Agency of Statistics (KAS) has published the Hotel Statistics in Kosovo in the first quarter of 2019 (Q1 2019). In Q1 2019, part of the survey was 218 hotels that operate in the territory of Kosovo. Most of the hotels are located in the region of Prishtina, Peja, and so on. In Q1 2019 the number of visitors (local and foreign) was 65,265, of which $41.85 \%$ were local visitors and $58.15 \%$ were foreign visitors, while the number of nights of stay was 104,907 , of which $39.70 \%$ by local visitors and $60.30 \%$ by foreign visitors. The largest number of visitors and their nights of stay is concentrated the region of Prishtina with 28,876 visitors with 48,561 night of stay. The largest number of foreign visitors is concentrated in Prishtina, Prizren and so on. As for foreign visitors, the largest number of them was from Albania, Turkey, Germany, etc.

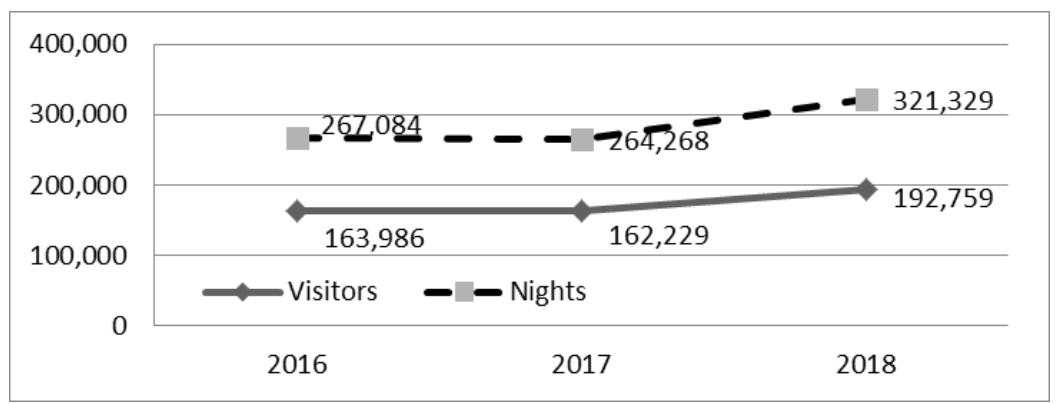

Figure 1. Graphical representation of the number of foreign visitors and their night stays in the period 2016-2018 Compiled by authors based on table data 
Figure 1 graphically shows the total number of foreign visitors and their night stays during the period 2016-2018. It is seen that from 2016 to 2017 there is a slight decrease in the number of foreign visitors and their night stays. However, in 2018 the number of foreign visitors and their night stays have increased; the number of visitors from 264,268 in 2017 increased to 321,329 in 2018 and their night stays from 162,229 in 2017 increased to 192,759 in 2018.

\section{CONCLUSIONS}

The travel and tourism industry is of particular importance because it contributes to the economic development of countries in general. So, it contributes to GDP growth. Tourism as an industry evolved more rapidly with the creation of the airline industry, which enabled faster transport of tourists from one place to another.

The movement of tourists through tourist destinations in different countries has made tourism develop globally. Nowadays the possibilities for free movement have increased and this has facilitated the global development of tourism. Nowadays both domestic and foreign tourism have a higher level of development as it's easier for tourists in general to visit tourist sites around the world, in those places that tourists prefer.

Regarding Kosovo, we can say that Kosovo has natural beauties, cultural heritage, historical monuments, etc., and all of which affect the way Kosovo is visited by tourists from all over the world. We noticed that the number of tourists visiting Kosovo has increased year after year, which means that the tourist potential in Kosovo is high. To keep up with the growing tourism trend, the government's budget allocated for tourism needs to be increased in order to protect and develop tourist destinations.

Kosovo also needs to become a member of the International Organizations for tourism and statistics so that tourism statistics can be always updated and the access in tourism statistics can be easier.

Concerning the number of foreign tourists, it turned out that the largest number of foreign visitors is concentrated in Prishtina, Prizren and so on. As for foreign visitors, the largest number of them was from Albania, Turkey, Germany, etc.

It should be noted that the number of foreign visitors and their night stays in Kosovo varied from one year to another. Thus, if we compare the years studied, we can say that the number of foreign visitors and their night stays was higher in 2016 compared to 2017. And also in 2018 there was again an increase in the number of foreign visitors and their night stays in Kosovo.

\section{REFERENCES}

Baker, D., Unni, R. (2018). Characteristics and Intentions of Cruise Passengers to Return to the Caribbean for Land-Based Vacations. Journal of tourism - studies and research in tourism, Issue 26, 1-9.

Belk, R. W., Costa, J. A. (1995). International Tourism: An Assessment and Overview. Journal of Macromarketing, SAGE journals, 15(2), 33-49.

Burkart, A. J., Medlik, S. (1981). Tourism: Past, Present and Future, Elsevier Science \& Technology Books, United Kingdom.

Gee, Y. Ch., Solá-Fayos, E. (1997). International Tourism: A Global Perspective, 1st Edition, World Tourism Organization, Madrid, Spain.

Herman, G. V., Deac, A. L., Ciobotaru, A. M., Andronache, I. C., Loghin, V., \& Ilie, A. M. (2017). The role of tourism in local economy development. Bihor County case study. Urbanism. Architecture. Constructions/Urbanism. Arhitectura. Constructii, 8(3), 265-274.

Herman, G. V., Peptenatu, D., Grama, V., \& Pintilii, R. D. (2018). Tourism and Local Development. Study Case: Băile Felix-Băile 1 Mai Tourism System, Bihor County, Romania. Analele Universitatii din Oradea, Seria Geografie, 28(1), 131-137.

Ilieș, D. C., Baias, S., Buhaș, R., Ilieș, A., Herman, G. V., Gaceu, O., \& Măduța, F. (2017). Environmental education in protected areas. Case study from Bihor County, Romania. GeoJournal of Tourism and Geosites, 19(1), $126-132$.

Işik, C., Günlü Küçükaltan, E., Taş, S., Akoğul, E., Uyrun, A., Hajiyeva, T., Turan, B., Dibro, A. H., Bayraktaroğlu, E. (2019). Tourism and Innovation: A literature review. Journal of Ekonomi, 1(2), 98-154.

Koja, V., Gorica, K. (2010). Bazat e Turizmit [The Fundamentals of Tourism], albPaper, Tirana, Albania.

Lew, A. A., Hall, M. C., Williams, M. A. (2004). A Companion to Tourism, Blackwell Publishing, USA.

Lickorish, J. L., Jenkins, L. C. (1997). An Introduction to Tourism, Butterworth-Heinemann, United Kingdom. 
Mowforth, M., Munt, I. (2016). Tourism and Sustainibility: Development, Globalisation and New Tourism in the Third World, Fourth Edition, Routledge, Taylor \& Francis Group, London and New York.

Page, J. S. (2019). Tourism Management, Sixth Edition, Routlende - Taylor \& Francis Group, London and New York.

Pender, L., Sharpley, R. (2005). The Management of Tourism, SAGE Publications, London, United Kingdom.

Reçica, F., Millaku, B. (2011). Ekonomia e Turizmit [Tourism Economy],The authors, Prishtina, Kosovo.

Reçica, F., Millaku, B. (2014). Hyrje në Turizëm [Introduction to Tourism], The authors, Peja, Kosovo.

Segui-Amortegui, L., Clemente-Almendros, J. A., Medina, R., Grueso Gala, M. (2019). Sustainability and Competitiveness in the Tourism Industry and Tourist Destinations: A Bibliometric Study. Sustainability, 11(22), 1-30.

Sharpley, R. (2020). Tourism, sustainable development and the theoritical divide: 20 years on. Journal of Sustainable Tourism, 28(11), 1932-1946.

Sivesan, S. (2020). Sustainable Tourism Development in Jaffna District. Journal of Tourism \& Hospitality, 9(3), 1-5.

Tahiri, A., Kovaçi, I. (2017). Menaxhimi në Turizëm: Qasje Teorike Menaxheriale [Management in Tourism: Theoritical Managerial Approach], Research Center, Peja, Kosovo.

Tătar, C. F., Herman, G. V., Dehoorne, O., \& Zarrilli, L. (2017). Ecotourism in the Danube Delta. Analele Universităţii din Oradea, Seria Geografie, 27(1), 122-132.

Theobald, F. W. (2005). Global Tourism, Third Edition, Elsevier, Butterworth-Heinemann, United Kingdom.

Wang, N. (2000). Tourism and Modernity: A sociological analysis, Elsevier Science, United Kingdom.

Wendt, J., Buhaş, R., \& Herman, G. V. (2019). Experience of the Baile-Felix Tourist System (Romania) For the Protection and Promotion of the Grey Seal as a Brend on the Hel Peninsular (Poland). Baltic Region/Baltijskij Region, 11(1), 109-116.

World Tourism Organization (UNWTO). (2018). Tourism for Development, Volume I: Key Areas for Action, Madrid, Spain.

*** USAID EMPOWER Private Sector: Analysis of the current situation in the tourism sector in Kosovo. This report was produced for review by the United States Agency for International Development (USAID) and Swedish International Development Cooperation Agency (SIDA), Prishtina, April, 2018. (https://mti.rksgov.net/desk/inc/media/BEE9A796-9FA3-4254-8528-AB86C722CFF2.pdf)

*** Tourism Development Through Efficient Policies and Legislation: Identifying potential reform steps in tourism policy and legislation. Democracy for Development Institute, Prishtina, July, 2017. (https://d4d-ks.org//wpcontent/uploads/2017/07/D4D_PI_10_SHQ_WEB.pdf)

*** Kosovo Agency of Statistics, Series 3: Economic Statistics, Hotel Statistics Q1 2019. (https://ask.rksgov.net/media/4926/hotel-statistics-q12019.pdf

Submitted:

March 09, 2020
Revised:

June 20,2020
Accepted and published online

August 03, 2020 